\title{
The Effect of the Size of Public Accounting Firms (KAP) and Specialist Auditors on Audit Quality with the Audit Committee as a Moderating Variable
}

\author{
Retnoningrum Hidayah ${ }^{1}$, Wisnu Darmawan ${ }^{2}$, Trisni Suryarini ${ }^{3}$, Dhini Suryandari ${ }^{4}$, Rita \\ Rahayu $^{5}$ \\ \{retnoningrum.hidayah@mail.unnes.ac.id ${ }^{1}$ \} \\ Universitas Negeri Semarang, Indonesia ${ }^{1,2,3,4}$ \\ Universitas Andalas, Indonesia ${ }^{5}$
}

\begin{abstract}
The audit quality becomes important in the realization of good corporate governance. There are several things that affect audit quality, namely the size of public accounting firm (KAP), specialist auditors, audit tenure, and so on. This study examines the influence of KAP size and specialist auditors on audit quality in banking companies in Indonesia. Furthermore, this study has a novelty on the use of audit committee variables as a moderating variable. The sample of this study is the audit report of banking company listed on the Indonesian Stock Exchange (IDX) in 2014-2018. Furthermore, the data analysis method uses MRA test with SPSS 21 . The result of this study indicate that auditor specialization has a negative effect on audit quality. Whereas, the size of the KAP has no effect on audit quality. Furthermore, there is a significant influence between KAP size on audit quality that is moderated by the audit committee. However, the audit committee cannot moderate the relationship of the influence of auditor specialization on audit quality. This research contributes to the scientific literature related to audit quality.
\end{abstract}

Keywords: Audit Quality, Audit Committee, KAP Size, Auditor Specialization.

\section{Introduction}

Audit quality is the possibility of auditor to find misstatements on client financial statement [1]. In determining misstatement, the auditor must have an attitude of professional skepticism. Misstatements can occur as a result of mistakes or fraud. Public Accountant Professional Standards (SPAP) is a reference set to a quality standard that must be obeyed by public accountants in the provision of services [2]. The auditor is responsible for complying with audits of financial statements.

Cases that have dragged the names of public accountants into many cases in Indonesia, such as irregularities in Garuda Indonesia's financial statements in 2018, caused a lot of polemic. It all started with the results of Garuda Indonesia's financial statements for the 2018 fiscal year. Garuda Indonesia Group posted a net profit of USD809.85 thousand or equivalent to Rp11.33 billion (assuming an exchange rate of Rp14,000 per US dollar). This figure jumped sharply compared to 2017 which suffered a loss of USD216.5 million, but the financial statements caused a polemic, because two Garuda Indonesia commissioners namely Chairal Tanjung and Dony Oskaria (currently not in office), considered the 2018 Garuda Indonesia financial statements were not in accordance with the Statement Financial Accounting Standards (PSAK). This is because Garuda Indonesia includes the receivables as 
income received from PT Mahata Aero Teknologi. PT Mahata Aero Teknologi itself has debts related to the installation of unpaid $\mathrm{Wi}-\mathrm{Fi}$.

Audit quality is a systematic and independent examination to determine activities, quality and results in accordance with the planned arrangements and whether these arrangements are implemented effectively and in accordance with the objectives. When the activities, quality and results are in accordance with the regulations and principles that have been determined, it can be said that the quality of the audit is high. KAP which is affiliated with KAP Big Four and has a high reputation can produce high audit quality. In addition, specialist auditors are more likely to detect errors and deviations from non-specialist auditors. Hence, specialist auditors tend to provide higher quality audit results than non-specialist auditors. High audit quality indicates that the company's activities, quality and performance are running well and accordingly. In banking companies, their performance can be seen from the financial reports that have been audited by the Public Accounting Firm.

When the banking company shows good company performance, the public and investor confidence will increase. The public will believe in saving their money and making loans to these banks. Furthermore, investors will be willing to invest. The existence of commercial banks in a modern economy is very important for the country's economy, especially in terms of maintaining financial stability, controlling inflation, the payment system, and the monetary authority.

Some previous studies show inconsistencies in audit quality research. Che et al. [3], Alsmairat et al. [4], Ibrahim \& Ali [5], Muliawan \& Sujana [6] shows that there is a positive influence on KAP size on audit quality. However, research Paputungan \& Kaluge [7], Atmojo \& Sukirman [8] shows that KAP size has a negative effect on audit quality. On the other hand, research conducted by Nurintiati \& Purwanto [9], Nizar [10], Nugroho [11] and Sari, Diyanti \& Wijayanti [12] stated that KAP size had no influence on audit quality. Then Tjun [13] and Fitriany [14] shows that auditor specialization has a negative effect on audit quality. Whereas Nurintiati \& Purwanto [9], Pramaswaradana \& Astika [15], Pertiwi, Hasan \& Hardi [16] stated that auditor specialization has no effect on audit quality. However, Sari, Diyanti \& Wijayanti [12] and Atmojo \& Sukirman [8] found that auditor specialization had a positive effect on audit quality.

In addition to the emergence of regulations regarding mandatory audit rotation, the formation of an audit committee in each company is one way to improve audit quality [17]. The audit committee was formed with the aim of overseeing the course of the external audit process and maintaining the relationship between the company's management and the external auditor. Audit committee oversight aims to reduce the existence of an emotional relationship between the company and the external auditor, which will reduce the independence of the external auditor itself and have an impact on audit quality. In addition, the existence of an audit committee is expected to be able to oversee negotiations on the determination of the use of Big Four and non-Big Four KAPs, specialist KAPs and KAP who do not have industry specialization in conducting an audit engagement. hence this paper examines the effect of the size of public accounting firms, and specialist auditors on financial companies in Indonesia with the audit committee as a moderating variable. 


\section{Literature Review and Hypothesis Development}

\subsection{Effect of KAP size on Audit Quality}

The large KAP size explains the ability of auditors to be independent and professional towards clients because they are less dependent on clients. Big KAP (Big 4 accounting firms) are believed to conduct higher quality audits compared to small KAP (Non-Big 4 accounting firms). KAP that has a good reputation are considered to be more efficient in conducting the audit process and will produce information in accordance with the fairness of the company's financial statements. Giri (2010) states that reputable KAP explains the existence of auditor independence in carrying out audit tasks. Choi et al. [18] state that large-scale KAPs are internationally well-known KAPs that provide higher quality audit services than small-scale KAPs

Alsmairat et al. [4] found that the size of the Public Accounting Firm (KAP) had a significant positive effect on audit quality. The results of the study showed that the KAP size had a significant influence on audit quality, indicating that the big four KAP or KAP affiliated with the big four KAP auditing the company's financial statements was able to influence audit quality. Based on this description, the following hypothesis is formulated:

H1: KAP size has a positive influence on audit quality.

\subsection{Effect of Change of Auditor Specialization on Audit Quality}

An auditor's experience of an industry's understanding of the company being audited is also very helpful in detecting fraud. Kallapur et al. [19] concerning the effect of market concentration audit on audit quality where the higher the market concentration, the lower the audit quality. In general, specialist accounting firms control market share in an industry so maintain market power in a particular industry, there is a possibility that specialist accounting firms are forced to sacrifice their independence in order to retain their clients [13]. H2: Auditor specialization has a negative influence on Audit Quality.

\subsection{The Role of Audit Committee in Moderating the relationship of KAP size to Audit Quality}

The external auditor becomes an independent party from outside the company, while the audit committee becomes an independent party from within the company. The audit committee has a function in providing views and suggestions regarding problems in the company's operations, policies and conducting internal controls [17]. Hence audit committee could minimize risk of fraud. The use of KAP affiliated with Big Four KAP and supported by a good audit committee so that the independence of auditors can survive well. Monitoring carried out by the audit committee during the audit process ensures that the audit is conducted properly so that it is considered capable of improving audit quality. Based on these descriptions, the researchers formulated the hypothesis as follows:

H3: The Audit Committee could moderate the relationship between KAP Size and Audit Quality

\subsection{The Role of the Audit Committee in Moderating the Relationship of the Auditor Specialization to Audit Quality}

The use of specialist public accountant services and supported by a qualified audit committee is expected to be able to produce quality audits that are reliable and reliable. Good 
communication between the audit committee and the public accountant will make the audit process can be carried out with appropriate procedures so that when encountering a problem, the solution will be easy to find and from that good audit quality will be produced. The presence of the audit committee as a supervisor is considered capable of limiting the auditor to maintain his market share for personal or group gain by sacrificing his independence and doing everything that can reduce audit quality. So that the audit quality produced by specialist auditors and non-specialist auditors can be of good quality.

H4: The Audit Committee could moderate the relationship between auditor specialization on Audit Quality.

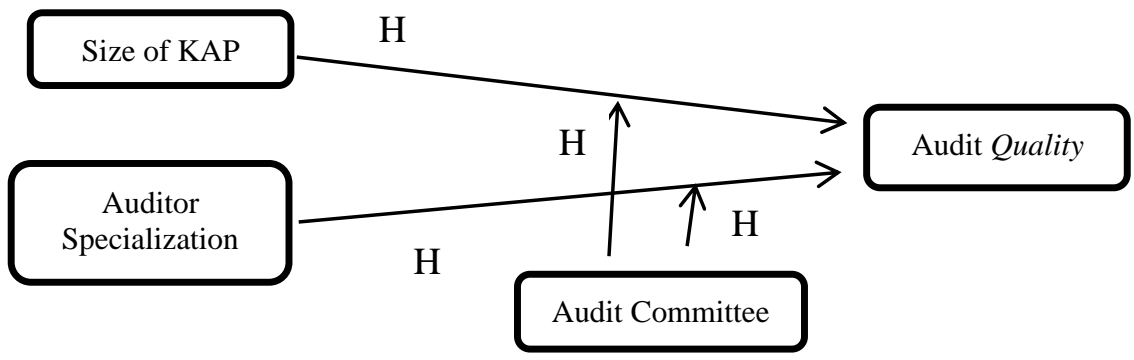

Fig 1. Research Model

\section{Research Methods}

\subsection{Data Collection}

This study uses quantitative methods and uses secondary data. The population is a banking sector company listed on the Indonesia Stock Exchange (IDX) for the 2014-2018 period. Sample selection used purposive sampling method. The total population is 220 , from the sampling conducted obtained a sample of 150 .

Table 1. Sample Criteria

\begin{tabular}{|l|c|}
\hline Number of banking companies listed on the IDX & 44 \\
\hline Banking companies registered after 2014 & $(3)$ \\
\hline $\begin{array}{l}\text { Companies that do not publish consecutive financial statements during the study } \\
\text { period }\end{array}$ & $(6)$ \\
\hline Banking companies that are not accompanied by independent auditor's report & 0 \\
\hline Amount of outlier data & $(5)$ \\
\hline Sample & 30 \\
\hline Number of observations (2014-2018) & 5 \\
\hline Final Sample & 150 \\
\hline
\end{tabular}

Table 2. Definition of Variable Operations

\begin{tabular}{cccclll}
\hline No. & Variable & \multicolumn{2}{c}{ Variable Definition } & \multicolumn{2}{c}{ Measurement } \\
\hline 1. & Audit Quality & $\begin{array}{l}\text { Audit quality is possibility } \\
\text { of }\end{array}$ & 1. & $\begin{array}{l}\text { Perform } \\
\text { calculations: }\end{array}$ & Total & Accrual \\
\hline
\end{tabular}




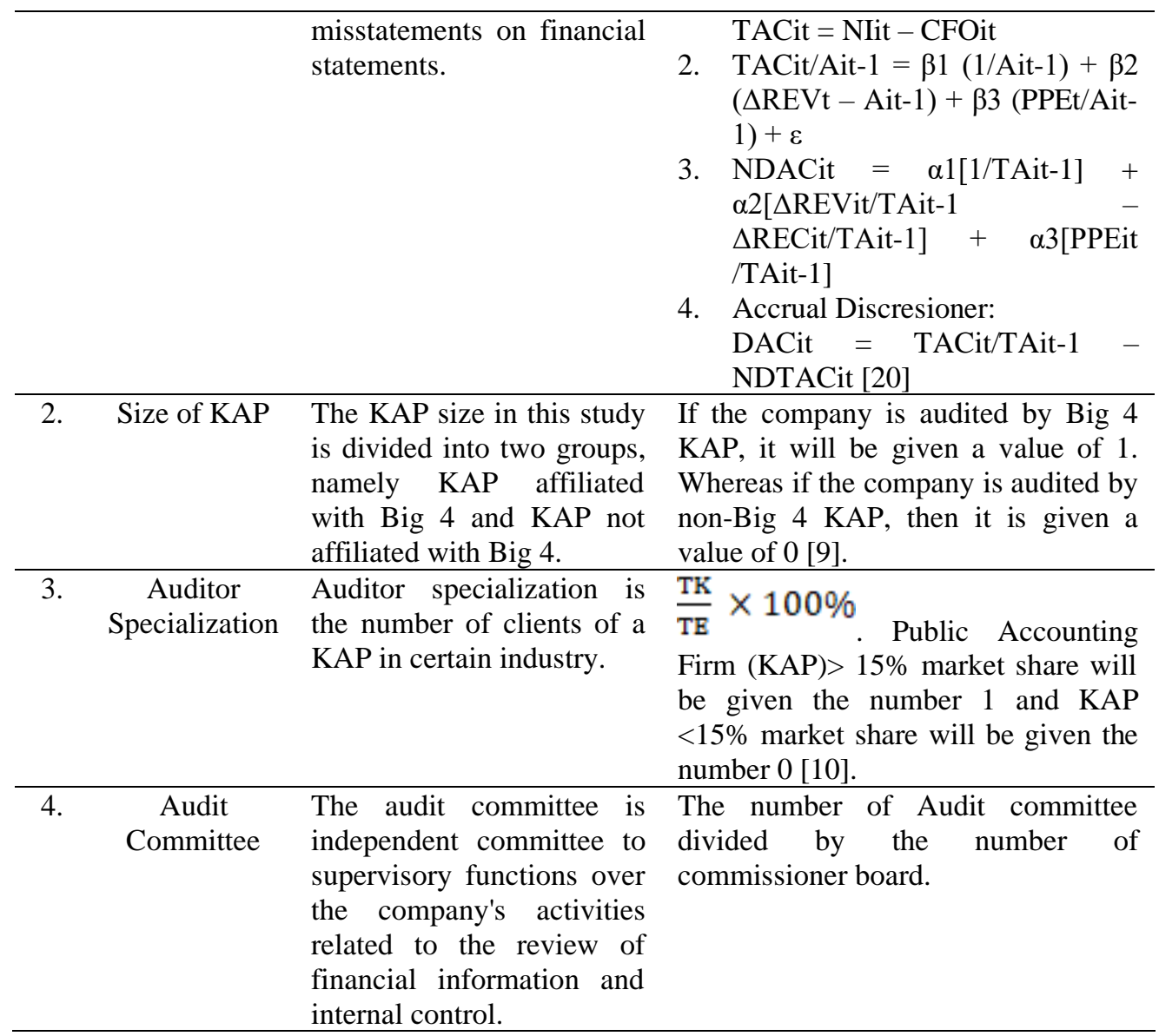

\subsection{Data Analysis}

Hypothesis testing is done with a Moderated Regression Analysis (MRA) to analyze the effect of audit tenure, KAP size, auditor specialization and audit fees on audit quality by using the audit committee as a moderating variable. This study uses an interaction test (MRA) to test the audit committee as moderating. The moderation variable used is the audit committee (KA). The audit committee in this study was measured based on the percentage of the existence of the audit committee.

\section{$4 \quad$ Results and Discussion}

\subsection{Descriptive Testing}

Based on table 3 shows that from the data processed as many as 150 , the audit quality variable which is proxied by discretionary accruals (DAC) has a range of 0,0006 to 0.2547. The lowest value of 0,0006 is owned by Bank QNB Indonesia Tbk. in 2017 and Bank Rakyat Indonesia (Persero) Tbk. 2016 showed that the company carried out accrual management by 
reducing its profits by 0.0006 . The highest value of 0.2547 is owned by Bank QNB Indonesia Tbk. 2014 showed that the company carried out accrual management by increasing its profit by 0.2547 . The average value (mean) of 0.051312 indicates that the average sample company in the 2014-2018 period carried out accrual management of 0.51312. The standard deviation produced in this study of 0.0455997 shows relatively small data deviations because the value is smaller than the mean (mean). The existence of a small data deviation indicates good and varied data distribution on audit quality variables.

Table 3. Descriptive Statistics

\begin{tabular}{l|ccccc}
\hline & $\mathrm{N}$ & Minimum & Maximum & Mean & Std. Deviation \\
\hline Size of KAP & 150 & 0 & 1 & .31 & .465 \\
Auditor Specialization & 150 & 0 & 1 & .31 & .463 \\
Audit Quality & 150 & .0006 & .2547 & .051312 & .0455997 \\
Audit Committee & 150 & .38 & 1.67 & .8829 & .32450 \\
Valid N (listwise) & 150 & & & \\
\hline \multicolumn{5}{r}{ Source: Secondary data processed by the author, 2020. }
\end{tabular}

Based on table 3, the proportion of the audit committee shows an average of 0.8829 with a standard deviation of 0.32408 . This means that the average number of members of the audit committee is $88.29 \%$ of the total number of commissioners in the company. The standard deviation of 0.32450 shows a relatively small data deviation because the value is smaller than the average value. The existence of a small data deviation indicates good and varied data distribution on audit committee variables. In table 3 the minimum value of the audit committee proportion is 0.38 owned by PT Bank Negara Indonesia (Persero) Tbk. 2014 and PT Bank Negara Indonesia (Persero) Tbk. 2016. While the maximum value of the audit committee proportion of 1.67 is owned by PT Bank Maspion Indonesia Tbk. 2014, PT Bank Harda Internasional Tbk. 2014 and PT Bank Maspion Indonesia Tbk. 2015.

\subsection{Results of Inferential Statistical Analysis}

\subsubsection{Normality Test}

In this study the results of the Kolmogorov-Smirnov test showed a figure of 0.326 where this indicates that a normal distribution was obtained because it was greater than 0.05 .

Table 4. Normality Test

\begin{tabular}{|c|c|c|}
\hline & & $\begin{array}{c}\text { Unstandardized } \\
\text { Residual }\end{array}$ \\
\hline $\mathrm{N}$ & & 150 \\
\hline \multirow{2}{*}{ Normal Parameters ${ }^{\mathrm{a}, \mathrm{b}}$} & Mean & .0000000 \\
\hline & Std. Deviation & .08703461 \\
\hline \multirow{3}{*}{ Most Extreme Differences } & Absolute & .078 \\
\hline & Positive & .078 \\
\hline & Negative & -.049 \\
\hline Kolmogorov-Smirnov Z & & .952 \\
\hline Asymp. Sig. (2-tailed) & & .326 \\
\hline
\end{tabular}

a. Test distribution is Normal.

b. Calculated from data. Source: SPSS Output, processed by the author, 2020. 


\subsubsection{Classic Assumption Test}

Based on Table 5, regression model is free from multicollinearity. The results of multicollinearity testing can be seen in table 5 below. Table 6 shows there is no positive or negative autocorrelation. Then, from picture 1 shows this research free from heteroskedasticity.

Table 5. Multicollinearity Test

\begin{tabular}{|c|c|c|c|c|c|c|c|}
\hline \multirow[t]{2}{*}{ Model } & \multicolumn{2}{|c|}{$\begin{array}{l}\text { Unstandardized } \\
\text { Coefficients }\end{array}$} & \multirow{2}{*}{$\begin{array}{c}\text { Standardized } \\
\text { Coefficients } \\
\text { Beta }\end{array}$} & \multirow[t]{2}{*}{$\mathrm{t}$} & \multirow[t]{2}{*}{ Sig. } & \multicolumn{2}{|c|}{$\begin{array}{c}\text { Collinearity } \\
\text { Statistics }\end{array}$} \\
\hline & $\mathrm{B}$ & Std. Error & & & & Tolerance & VIF \\
\hline (Constant) & .023 & .011 & & 2.091 & .038 & & \\
\hline Size of KAP & .010 & .008 & .098 & 1.228 & .221 & .986 & 1.014 \\
\hline Auditor Specialization & .024 & .008 & .248 & 3.134 & .002 & .994 & 1.006 \\
\hline Audit Committee & .020 & .011 & .140 & 1.758 & .081 & .983 & 1.017 \\
\hline
\end{tabular}

a. Dependent Variable: Audit Quality

Source: Source: SPSS Output, processed by the author, 2020.

Table 6. Durbin-Watson Test

Model Summary ${ }^{\mathrm{b}}$

\begin{tabular}{cccccc}
\hline Model & $\mathrm{R}$ & R Square & $\begin{array}{c}\text { Adjusted R } \\
\text { Square }\end{array}$ & $\begin{array}{c}\text { Std. Error of the } \\
\text { Estimate }\end{array}$ & $\begin{array}{c}\text { Durbin- } \\
\text { Watson }\end{array}$ \\
\hline 1 & $.145^{\mathrm{a}}$ & .021 & .014 & .04314194 & 1.973 \\
\hline
\end{tabular}

a. Predictors: (Constant), LAG_RES1

b. Dependent Variable: Unstandardized Residual

Source: SPSS Output, processed by the author, 2020.

Picture 2. Scatterplot

Scatterplot

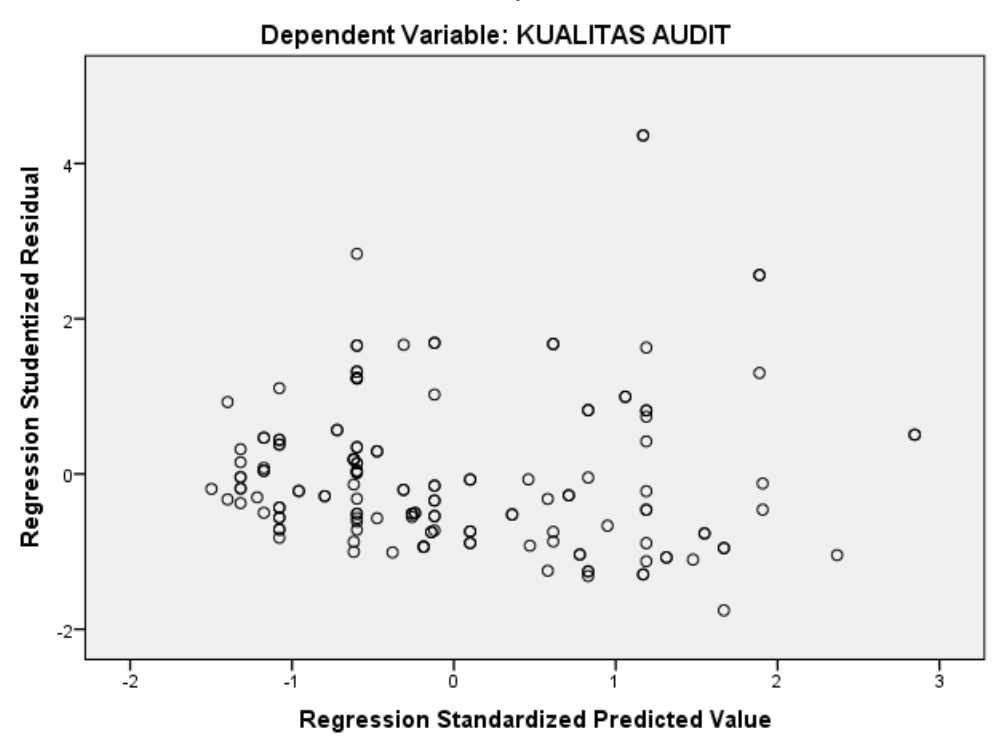

Source: SPSS Output, processed by the author, 2020. 


\subsection{Hypothesis Test}

Table 7 shows that the results of $\mathrm{H} 1$ testing obtained a significance value of 0.453 (> $0.05)$ so that $\mathrm{H} 2$ is rejected. These results are in line with research conducted by Nurintiati \& Purwanto [9], Nizar [10], Nugroho [11], Sari, Diyanti \& Wijayanti [12] and Apriani [21] who found that the size of the Public Accounting Firm had no effect on audit quality. KAPs that are affiliated with big four KAPs do not tend to produce better audit quality than KAPs that are not affiliated with big four KAPs. An auditor who works both in the big four KAP and nonbig four KAP they are bound by professional competency standards so that wherever they work for the big four or non-big four KAP, they will carry out checks in accordance with the established regulations and standards [22].

Table 7. Hypothesis Test Results

\begin{tabular}{|c|c|c|c|c|c|c|}
\hline & \multirow[t]{2}{*}{ Model } & \multicolumn{2}{|c|}{$\begin{array}{c}\text { Unstandardized } \\
\text { Coefficients }\end{array}$} & \multirow{2}{*}{$\begin{array}{c}\begin{array}{c}\text { Standardized } \\
\text { Coefficients }\end{array} \\
\text { Beta } \\
\end{array}$} & \multirow[t]{2}{*}{$\mathrm{t}$} & \multirow[t]{2}{*}{ Sig. } \\
\hline & & $\mathrm{B}$ & Std. Error & & & \\
\hline \multirow{5}{*}{1} & (Constant) & .045 & .006 & & 7.476 & .000 \\
\hline & Size of KAP & -.007 & .009 & -.072 & -.752 & .453 \\
\hline & Auditor Specialization & .027 & .008 & .275 & 3.439 & .001 \\
\hline & Interaction of_KA_KAP & .033 & .012 & .297 & 2.866 & .005 \\
\hline & Interaction of_KA_SA & -.012 & .008 & -.132 & -1.507 & .134 \\
\hline
\end{tabular}

a. Dependent Variable: Audit Quality

Source: Secondary data processed by the author, 2020.

$\mathrm{H} 2$ test results obtained a significance value of $0.001(<0.05)$ so that $\mathrm{H} 2$ is accepted. This result is consistent with research conducted by Tjun [13], Fitriany [14] and Kallapur [19] who found that auditor specialization had a positive effect on discretionary accruals or had a negative effect on audit quality. In general, auditors or specialized accounting firms control market share in an industry. To maintain market power in a particular industry, it is possible that auditors or KAP specialists are forced to sacrifice their independence in order to retain their clients.

The H3 test results obtained a significance value of $0.005(<0.05)$, so that $\mathrm{H} 3$ is accepted. The results of this study are in line with research conducted by Atmojo and Sukirman [8] who found that the audit committee was able to moderate the relationship between KAP size and audit quality. This happened because the audit committee and KAP did not support each other's work. In addition, the work pressure received by KAP because many clients use KAP services affiliated with Big Four KAP compared to KAP affiliated with non-Big Four KAP can reduce audit quality. Excessive workload on KAP will negatively impact the quality of audits produced [7][23].

The H4 test shows significance value of 0.134 (>0.05), so that $\mathrm{H} 4$ was rejected. These results indicate that the existence of an audit committee does not affect the interests of specialist auditors to maintain market power and their clients. To maintain market power in an industry, it is possible that auditors or KAP specialists are forced to sacrifice their independence in order to retain their clients and this causes a decline in audit quality [13][14][19]. 


\subsection{Influence of KAP size on Audit Quality}

This shows that the KAP size has no effect on audit quality, so the second hypothesis is rejected. Nurintiati and Purwanto [9] state that KAP size does not have an influence on audit quality because local KAP affiliated with Big Four KAP are more focused on attracting and gaining clients. Sari, Diyanti \& Wijayanti [12] state that the KAP size that has no effect on audit quality indicates that non-Big Four KAPs have improved their quality in conducting and producing audit services so that in determining the choice of KAP, the company no longer makes Big Four or non-Big Four KAP as the main consideration.

The results of this study break the agency theory that underlies that the company owner (principal) cooperates with the Big Four KAP to conduct an examination of the financial statements presented by management to assess the fairness of the financial statements presented in the hope of being able to produce better and reliable audit quality. The results of this study provide empirical evidence that KAP size does not affect audit quality.

These results are in line with research conducted by Nizar [10], Nugroho [11] and Apriani [21] who found that the size of the Public Accounting Firm had no effect on audit quality. KAPs that are affiliated with big four KAPs do not tend to produce better audit quality than KAPs that are not affiliated with big four KAPs. An auditor who works both in a big four KAP and a non-big four KAP they are bound by professional competency standards so that wherever they work at a big four or non-big four KAP, they will carry out checks in accordance with the established regulations and standards [22].

\subsection{Influence of Auditor Specialization on Audit Quality}

This study shows that auditor specialization has a significant positive effect on discretionary accruals or a significant negative effect on audit quality so that the third hypothesis is accepted. Tjun [13] found that auditor specialization has a negative effect on audit quality. These results break the agency theory that underlies the relationship and conflict of interest between management (agent) and company owner (principal). The conflict of interest requires an independent third party to evaluate and check the performance of management through the financial statements presented, the owner of the company contracts the KAP or auditor who specializes in an industry. However, the results showed different things, where the appointment of specialist auditors to audit financial statements presented by management tended to reduce audit quality.

This result is consistent with research conducted by Fitriany [14] and Kallapur [19] who found that auditor specialization has a positive effect on discretionary accruals or negatively affects audit quality. In general, auditors or specialized accounting firms control market share in an industry. It is possible that auditors or KAP specialists are forced to sacrifice their independence in order to retain their clients. The decline in audit quality is due to the decrease in independence greater than the increase in audit quality due to their specialization, because their independence is disrupted, then audit quality decreases [14].

\subsection{The Role of the Audit Committee in Moderating the relationship of KAP size to Audit Quality}

The results of interactions between audit committee variables and KAP size significantly influence discretionary accruals with a positive direction or a negative direction on audit quality. These results mean that the audit committee as a moderating variable weakens the influence of the KAP size on audit quality. Based on these results break the agency theory previously mentioned that the presence of the audit committee could oversee the emotional 
relationship that is too close between KAP with management. The presence of the audit committee in conducting oversight that is too strict and rigid makes the auditor feel limited in carrying out and carrying out audit procedures. In addition, poor communication between public accounting firms and audit committees can be one of the causes that can reduce audit quality, in other words it can reduce audit quality.

The results of this study are in line with research conducted by Atmojo and Sukirman [8] who found that the audit committee was able to moderate the relationship between KAP size and audit quality. This happened because the audit committee and KAP did not support each other's work. In addition, the work pressure received by KAP because many clients use KAP services affiliated with Big Four KAP compared to KAP affiliated with non-Big Four KAP can reduce audit quality. Excessive workload on KAP will negatively impact the quality of audits produced [7][23].

\subsection{The Role of the Audit Committee in Moderating the Relationship of the Auditor Specialization to Audit Quality}

Based on the results of the study showed the interaction between audit committee variables and auditor specialization did not have a significant effect on audit quality so that the audit committee was unable to moderate the influence of auditor specialization on audit quality [24], so the fifth hypothesis was rejected. The presence of the audit committee is not able to moderate the influence of auditor specialization on audit quality because specialist auditors tend to have more knowledge in certain industry fields and have experience auditing companies with different systems, so the presence of the audit committee has no effect.

In addition, this paper breaks the agency theory previously mentioned that the presence of the audit committee could oversee specialist auditors to carry out audit activities according to good procedures. The presence of the audit committee in supervising specialist auditors is unable to weaken or strengthen audit quality. Poor communication during the supervision and monitoring period is the reason why the presence of the audit committee does not affect the relationship between auditor specialization and audit quality.

These results indicate that the existence of an audit committee does not affect the interests of specialist auditors to maintain market power and their clients. To maintain market power, it is possible that auditors or KAP specialists are forced to sacrifice their independence in order to retain their clients and this causes a decline in audit quality [13][14][19].

\section{Conclusions}

This research give evidence that KAP size does not affect audit quality. While auditor specialization has a negative effect on audit quality. The audit committee is unable to strengthen or weaken the influence of auditor specialization on audit quality. However, the audit committee could weaken the influence of KAP size on audit quality. In this study, there are limitations, namely the sample used only in banking sector companies listed on the Indonesia Stock Exchange. Another limitation, the measurement of KAP size variables does not use data from the IAPI. Further research is expected to examine the KAP size used uses a broader assessment such as KAP affiliated with international KAP. Furthermore, it can use companies in other sectors with periods of more than 5 years. 


\section{References}

[1] Watkins, L. Ann, W. Hillison, and S. E. Morecroft, "Audit Synthesis of Theory And Empirical Evidence," J. Account. Lit., vol. 23, pp. 153-193, 2004.

[2] Pemerintah Indonesia, "Undang-Undang No. 5 Tahun 2011 Yang Mengatur Tentang Akuntan Publik," Lembaran Negara RI Tahun 2011, No. 5215. Sekr. Negara. Jakarta, 2011.

[3] L. Che, O.-K. Hope, and J. C. Langli, "How Big-4 Firms Improve Audit Quality," Manage. Sci., pp. 1-21, 2020.

[4] Alsmairat, Y. Yaseen, W. S. Yusoff, M. A. Ali, and A. N. Ghazalat, "The Effect of Audit Tenure and Audit Firm Size on The Audit Quality: Evidence from Jordanian Auditors," Int. J. Bus. Technopreneursh., vol. 9, no. 1, pp. 15-24, 2019.

[5] M. Ibrahim and I. Ali, "Impact of Audit Fees on Audit Quality of Conglomerates Companies in Nigeria," Int. J. Serv. Sci. Manag. Eng., vol. 5, no. 1, pp. 1-8, 2018.

[6] E. K. Muliawan and I. K. Sujana, "Pengaruh Ukuran Kantor Akuntan Publik, Auditor Switching Dan Audit Tenure Pada Kualitas Audit," E-Jurnal Akunt. Univ. Udayana, vol. 21, no. 1, pp. 534-561, 2017.

[7] R. D. Paputungan and D. Kaluge, "Pengaruh Masa Perikatan Audit, Rotasi Audit dan Ukuran Kantor Akuntan Publik Terhadap Kualitas Audit,” J. Reviu Akunt. dan Keuang., vol. 8, no. 1, pp. 93-103, 2018.

[8] R. T. Atmojo and Sukirman, "Effect of Tenure, Audit Specialization, and KAP's Reputation on the Quality of Audit Mediated by Audit Committess," Account. Anal. J., vol. 8, no. 1, pp. 6673, 2019.

[9] A. A. Nurintiati and A. Purwanto, "Pengaruh Tenure KAP, Ukuran KAP Dan Audit Fee Terhadap Kualitas Audit Dengan Moderasi Komite Audit," Diponegoro J. Account., vol. 6, no. 1, pp. 1-13, 2017.

[10] A. A. Nizar, "Pengaruh Rotasi, Reputasi dan Spesialisasi Auditor Terhadap Kualitas Audit (Studi Empiris pada Perusahaan Manufaktur Listed di BEI)," J. Ilm. Akunt. Kompartemen, vol. XV, no. 2, 2017.

[11] L. Nugroho, "Analisa Faktor-faktor Yang Mempengaruhi Kualitas Audit (Studi Empiris Pada Perusahaan Manufaktur Industri Sektor Barang Konsumsi Yang Terdaftar di Bursa Efek Indonesia Tahun 2014-2016)," J. Maneksi, vol. 7, no. 1, 2018.

[12] S. P. Sari, A. A. Diyanti, and R. Wijayanti, "The Effect of Audit Tenure, Audit Rotation, Audit Fee, Accounting Firm Size and Auditor Specialization to Audit Quality," Ris. Akunt. dan Keuang. Indones., vol. 4, no. 3, 2019.

[13] Tjun, "Pengaruh Tenor, Ukuran, Dan Spesialisasi Kantor Akuntan Publik Terhadap Kualitas Audit," J. Muara Ilmu Ekon. dan Bisnis, vol. 2, no. 2, pp. 472-484, 2018.

[14] S. U. Fitriany, D. Martani, and H. Rosietta, "Pengaruh Tenure, Rotasi dan Spesialisasi Kantor Akuntan Publik (KAP) Terhadap Kualitas Audit: Perbandingan Sebelum dan Sesudah Regulasi Rotasi KAP di Indonesia," J. Akunt. dan Keuang., vol. 17, no. 1, pp. 12-27, 2015.

[15] I. G. N. I. Pramaswaradana and I. B. P. Astika, "Pengaruh Audit Tenure, Audit Fee, Rotasi Auditor, Spesialisasi Auditor, dan Umur Publikasi pada Kualitas Audit," E-Jurnal Akunt. Univ. Udayana, vol. 19, no. 1, pp. 168-194, 2017.

[16] N. P. Pertiwi, A. Hasan, and Hardi, "Pengaruh Masa Perikatan Audit, Spesialisasi Industri KAP, Reputasi KAP dan Komite Audit terhadap Kualitas Audit (Studi Empiris pada Perusahaan Manufaktur di BEI Tahun 2011-2014),” J. Akunt., vol. 4, no. 2, pp. 147-160, 2016.

[17] I. P. Nuratma, "Pengaruh Tenur dan Reputasi Kantor Akuntan Publik Pada Kualitas Audit Dengan Komite Audit Sebagai Variabel Moderasi (Studi Kasus Pada Perusahaan Manufaktur Yang Terdaftar di BEI tahun 2004-2009)," J. Ekon., vol. 1, 2011.

[18] J. H. Choi, C. Kim, J. B. Kim, and Y. Zang, "Audit Office Size, Audit Quality, and Audit Pricing," Audit. A J. Pract. Theory, vol. 29, no. 1, pp. 73-79, 2010.

[19] S. Kallapur, "Audit Market Competition and Audit Quality," 2008.

[20] S. V. Siregar, F. Amarullah, A. Wibowo, and V. Anggraita, "Audit Tenure, Auditor Rotation, and Audit Quality: The Case of Indonesia," Asian J. Bus. Account., vol. 5, no. 1, pp. 55-74, 
2012.

[21] T. Apriani, "Pengaruh Tenure KAP, Ukuran KAP, Spesialisasi Auditor, Audit Fee dan Workload Terhadap Kualitas Audit Dengan Dimoderasi Komite Audit (Studi Empiris Pada Perusahaan Manufaktur Yang Terdapat di Bursa Efek Indonesia Tahun 2015-2017),” J. Maksi, vol. 5, no. 1, 2020.

[22] T. Pratoomsuwan, "Audit Prices and Big 4 Fee Premiums: Further Evidence from Thailand," $J$. Account. Emerg. Econ., vol. 7, no. 1, pp. 2-15, 2017.

[23] N. F. Nadia, "Pengaruh Tenur KAP, Reputasi KAP dan Rotasi KAP terhadap Kualitas Audit," J. Akunt. Bisnis, vol. XIII, no. 26, 2015.

[24] L. W. Setiawan and Fitriany, "Pengaruh Workload dan Spesialisasi Auditor terhadap Kualitas Audit dengan Kualitas Komite Audit sebagai Variabel Pemoderasi," J. Akunt. dan Keuang. Indones., vol. 8, no. 1, 2011. 